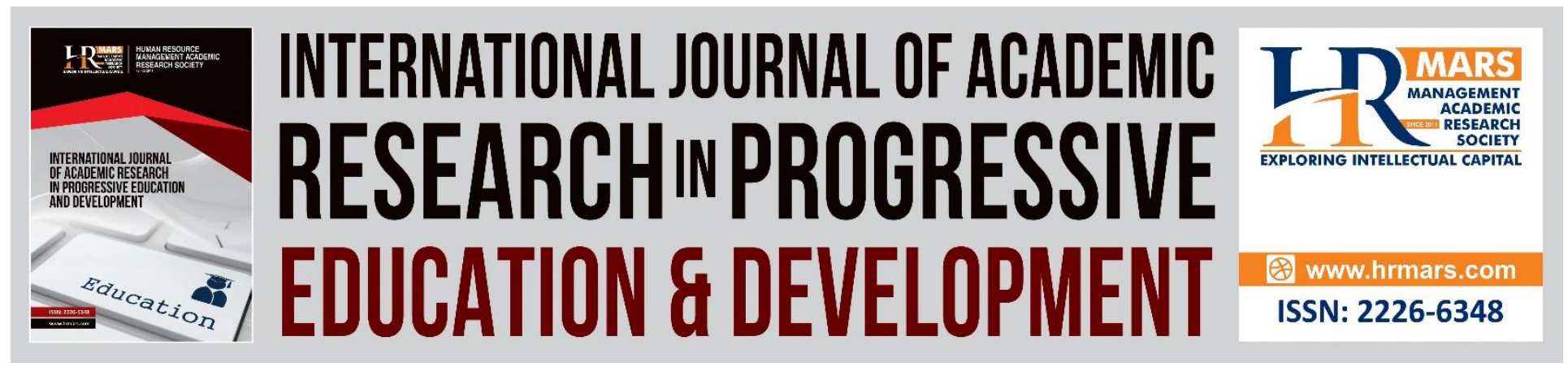

\title{
Review On Factors Affecting Micro Entrepreneur Performance In Malaysia: A Conceptual Model
}

Habsah Mohamad Sabli, Hamrila Abdul Latiff, Mohammad Fardillah Bin Wahi

To Link this Article: http://dx.doi.org/10.6007/IJARPED/v7-i3/4572

DOI: $10.6007 /$ IJARPED/v7-i3/4572

Received: 21 May 2018, Revised: 18 June 2018, Accepted: 13 July 2018

Published Online: 20 July 2018

In-Text Citation: (Sabli, Latiff, \& Wahi, 2018)

To Cite this Article: Sabli, H. M., Latiff, H. A., \& Wahi, M. F. Bin. (2018). Review On Factors Affecting Micro Entrepreneur Performance In Malaysia: A Conceptual Model. International Journal of Academic Research in Progressive Education and Development, 7(3), 539-548.

\section{Copyright: (C) 2018 The Author(s)}

Published by Human Resource Management Academic Research Society (www.hrmars.com)

This article is published under the Creative Commons Attribution (CC BY 4.0) license. Anyone may reproduce, distribute, translate and create derivative works of this article (for both commercial and non-commercial purposes), subject to full attribution to the original publication and authors. The full terms of this license may be seen at: $\underline{\text { http://creativecommons.org/licences/by/4.0/legalcode }}$

Vol. 7, No. 3, July 2018, Pg. 539 - 548

http://hrmars.com/index.php/pages/detail/IJARPED

JOURNAL HOMEPAGE

Full Terms \& Conditions of access and use can be found at http://hrmars.com/index.php/pages/detail/publication-ethics 


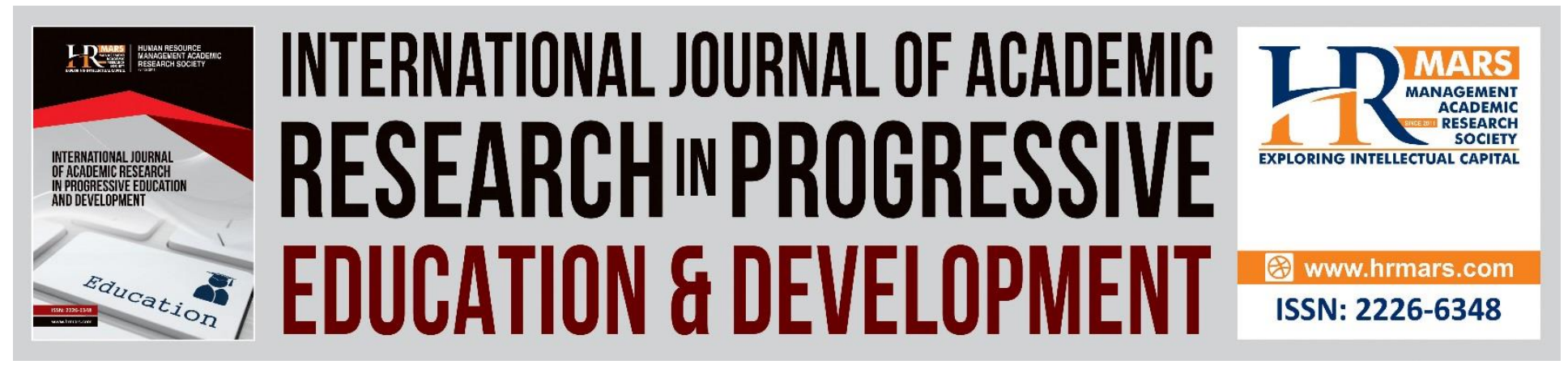

\title{
Review On Factors Affecting Micro Entrepreneur Performance In Malaysia: A Conceptual Model
}

\author{
Habsah Mohamad Sabli* and Hamrila Abdul Latiff \\ Faculty of Economics and Business, Universiti Malaysia Sarawak \\ Mohammad Fardillah Bin Wahi \\ Polytechnics Mukah Sarawak
}

\begin{abstract}
Micro entrepreneur performance has severally discussed by scholars around the world. The micro entrepreneur performance not only measures by financial but also non-financial. Resources Based Theory (RBV) and Entrepreneurial Competency Theory play important role as determination of firm performance. The antecedent includes financial literacy, financial access, dynamic incentives as factors effecting micro entrepreneur firm performance. There are still lack of study and information on the relationships between f financial literacy, financial access, and dynamic incentives with micro entrepreneur performance. Consequently, misspecification of model and omission of measures due to deficiencies in analysis may likely lead to irrelevant conclusion to knowledge and practices. Hence, the study proposed a research framework that bridges internal and external integration factors effecting micro entrepreneur performance in Malaysia.
\end{abstract}

Keywords: Financial Literacy; Financial Access, dynamic Incentives, Micro entrepreneur Performance and Malaysia.

\section{Introduction}

Micro enterprises institute comprises of $78.7 \%$ of all businesses in Malaysia and provide employment for over 1.2 million employees with more than four-fifths, of micro enterprises $87.7 \%$, are in the services sector, more important development in the retail, food and transportation sub-sectors (Zarina \& Wan 2009). Even though these micro enterprises are small, they are responsive and capable of taking benefit of positions which larger enterprises are unable to embark on successfully (Banks Negara Report, 2010). Development Finance Institutions (DFIs), Cooperatives and Micro Finance institutions (MFIs) also have an important role in serving niche groups of customers due to their vital contributions in the economy of Malaysia. Microfinance is the provision of small loans to very poor people for self-employment projects to generate income. The entrepreneur gain capital from the micro finance called micro entrepreneur 


\section{INTERNATIONAL JOURNAL OF ACADEMIC RESEARCH IN PROGRESSIVE EDUCATION AND}

DEVELOPMENT

Vol. 7, No. 3, July 2018, E-ISSN: 2226-6348 @ 2018 HRMARS

because the capital are small compare to loan provided by bank The aims of microfinance to fight poverty and serve people who would not have access to a loan from a formal financial institutions.. Objective of the microfinance to reduce poverty, to create employment and to encourage the new development in business. Microfinance programmed in Malaysia has been implemented since 1987 as one of the poverty eradication strategies in the country. There are four large microfinance institutions in Malaysia namely AIM, YUM, TEKUN and SEDC that targeted to different groups of people. In Malaysia, year 2016 (98.5\%) business establishments in Malaysia are SME which Microenterprise contribute to 693,670SMEs (76.5\%) overall of 907,065 establishments http://www.smecorp.gov.my. Substances with the microfinance provider, micro entrepreneur own ability and knowledge such as financial literacy plays important role in performance.

Financial literacy is very important for micro entrepreneurs in developing their business. Managers with deficiency of financial literacy knowledge will have logged minimal or no improvement for the their business (Lusimbo \& Muturi, 2016). The actual relevance of financial knowledge in order to have a successful entrepreneurship remains a topic for conversation. The study done by, Abiodun and Entebang (2016) revealed that financial literacy can be a particular difficulty for smaller businesses and enterprises. Microfinance tend to have more achievable rates involving job expansion, but organizations are being stunt along with financial literacy problems. Secondly, numerous studies been discussed on the lack of capital and poverty among micro entrepreneurs are financially more constrained than large firms are and are less likely to have access to formal finance (Beck \& Demirguc-Kunt, 2006). Financial access which contribute to source of capital for starting and managing of assets allocation and business growth. Therefore, some micro entrepreneurs will gain sources of funding from informal organizations such as pawnshops, which contribute to the failure of business. Common measures of financial access include account ownership, utilization of a variety of financial services and ability to obtain services from various financial service providers (Kumar, 2005). Thirdly, micro entrepreneur secured with agreement and high management cost, example AIM charge $10 \%$ yearly for one loan scheme. Loan granted without collateral and interest rates lead to moral hazards and asymmetric information. Hence dynamic incentives been introduced to prevent strategic default. Lack of financial literacy among entrepreneur in managing their credit and resource lead to unmanageable loan which entrepreneur tied with more than one loans. The question was if micro entrepreneur have more than one loan and the duration is five years, how much actually the micro entrepreneur paid back? This situations lead to questions on both sides, how effective the Micro entrepreneur provider and micro entrepreneur managing their credit. One of the microfinance objective to poverty provision, which increase household and business income, education, retirement, and wellbeing. Lastly, micro entrepreneur performance not only measure by financial but also non-financial. In financial, profitability, measures such as return on equity and return on assets, tend to summarize performance in all areas of the business. Understanding the important development of microfinance do not only generate economy, but also helps the poor in rural and urban areas. Our study focuses on understanding the impact of financial literacy, financial access, and dynamic incentives towards micro entrepreneur performance in Malaysia. 
Vol. 7, No. 3, July 2018, E-ISSN: 2226-6348 ㄷ 2018 HRMARS

\section{Literature Review}

This section will highlight the review of important studies relevant to RBV (Resource Based View), entrepreneurial competencies, financial literacy, financial access, dynamic incentives and micro entrepreneur performance.

\section{Entrepreneur and Resource Based View Theory (RBV)}

Resource Based view is important in managing firm resources in delivering competitive advantages, including both tangible (e.g. equipment) and intangible (e.g. process knowledge) assets. This includes assistance in production, transportation and services (Grant \& Barney, 1991). The success of the firm can be determined by how the use of resources which can be both physical and intangible, including; physical assets, logical and cultural asset, such as principal equipment, skills, copyrights, finance and leaders (Hafez et al. 2007).

\section{Entrepreneur and entrepreneurial Competency}

According to Boyatzis (1982) entrepreneurial competencies relate to an ability to scan for desirable opportunities with knowledge, skills and abilities that are required to carry out entrepreneurial characters. Thus, the entrepreneur is more mobile than other competitors due the opportunity. This was supported by Shane and Venkataraman (2000) that opportunity recognition activities are the main driver of entrepreneurship. Adapting to environmental opportunities enables entrepreneurs to understand the needs of today's consumers in line with the world's current movement.

\section{Entrepreneur Financial Literacy and Microfinance Performance}

Fatoki (2014) reported the failure percentage of new micro enterprises in South Africa as critical. The level of financial literacy of the owners of new micro enterprises is at a low level, whereby the new micro entrepreneurs are not involved in formal financial planning, budgeting and control and merely retain some records of account. There are major weaknesses in finance and information related skills, use of technology and risk management, as most of the respondents recognize commercial banks as a source of finance but nonetheless do not understand the sources of equity finance and the necessities to obtain a credit.

Another research was conducted by Kotze (2008). According to author, a deficiency of financial skills analysis plus management viewed as entrepreneur's forte. Entrepreneurs and managing teams regard the concept of financial management as terrifying. Capability of handling finances wisely is one of the critical managerial competencies; therefore this can lead to lack of success in new venture formation and growth.

\section{Entrepreneur Financial Access and Micro entrepreneur Performance}

In a study on the effects of finance on the performance of microenterprises in Sri Lanka, Del Mel (2008) established that financial literacy improved the usage of financial products by the enterprises, which in turn improved their performance. Nunoo et al. (2012) studied utilization of financial services by SMEs in Ghana have confirmed that financially literate entrepreneurs were more likely to access and utilize financial services, which in turn improved the performance of their enterprises. Kebede et al. (2015) also established that financial literacy influences financial access and that this had a negative influence on the performance of small enterprises in Kenya. 


\section{Entrepreneur Financial Literacy and Dynamic Incentives}

Dynamic incentives motivates borrower to increase their repayment gains. This was supported by Shapiro (2015) that single dipping and double dipping in dynamic incentives shows the same result which more favorable and contributes to the business growth. Hence, this implies that the defaulting rates along the double-dipping equilibrium are lesser. The practice of progressive lending in dynamic incentives has proven not only to be for joint liability but also for single help groups in improving the loan size and supply of financial services to the poor is found to be efficient and sustainable. It fulfilled the hole between inaccessible formal banking sector and also high cost informal sector (Kumar K, 2012a).

Micro entrepreneurs must attend courses, training or programs to increase their knowledge of financial literacy for the management of their business. The loan taken cannot cover the overall cost of the business which causes them to refinance or take on dynamic incentives. Dynamic incentives allow for a reputation accrual effect, where each borrower can progressively accomplish higher borrowing margins contingent on successful loan settlement (See Sebsted \& Cohen, 2000).

Dynamic Incentives and Micro entrepreneur Performance

Dynamic incentives require giving credit to one borrower at a time under the condition that the previous borrower repaid her loan (Sinn, 2009). Support by Ray (1998) proves that the sequential lending can also avoid default payment from borrowers. Research finding by Guha and Chowdhury (2013) shows dynamic incentives as a contributor to the phenomenon of the default borrower. Furthermore, it examines the interaction of dynamic incentives with micro entrepreneur performance, an aspect that has thus far been ignored in the literature. A study by Hering and Musshoff (2015) informed that microfinance makes no difference between farmer against non-farmers when taking dynamic incentives and offering the same amount of collateral to further their loan. The farmers faced by the seasons for their harvest, shall have uncertainty about their income. The similar research with different finding makes this research more interest to study.

Financial Literacy, Dynamic Incentives, and Micro entrepreneur Performance

Micro entrepreneurs must attend courses, training or program to increase their knowledge or financial literacy in managing their business. The loan taken cannot cover the overall cost of the business which causes them to refinance or take on dynamic incentives. Dynamic incentives allow for a reputation accrual effect, where each borrower can progressively accomplish higher borrowing margins contingent on successful loan settlement (See Sebsted \& Cohen, 2000).

The microfinance methodologies and innovations used for measuring microcredit success include group lending (where a small group of neighbors is jointly liable for individual loans), dynamic incentives (using access to future loans as incentives to repay the current one), regularrepayment schedules and using collateral as substitutes (Morduch, 1999). Using dynamic incentives, in the context of individual lending, indicates how microfinance can become a sustainable development alternative, especially in rural areas where markets are thicker and micro entrepreneurs are very profitable, where costs of outreach are lower, and in less risky locations (Alexander Tedeschi, 2006). Support with the findings from Cassar et al. (2007) in which repayment under dynamic incentives by individuals which performs as part of a groups or entity 
INTERNATIONAL JOURNAL OF ACADEMIC RESEARCH IN PROGRESSIVE EDUCATION AND DEVELOPMENT

Vol. 7, No. 3, July 2018, E-ISSN: 2226-6348 @ 2018 HRMARS

and the confidence of the borrowers within the group shall be determined for the success of their next loan and also for business growth.

\section{Conceptual Model}

\section{Proposed Conceptual Model}

The conceptual framework developed for this study was drawn from various theoretical perspectives including resource based view theory and entrepreneurship competency theory Entrepreneur financial literacy, the independent variable comprises of two concepts, namely entrepreneur and financial literacy. The study done by Man et al., (2002), an entrepreneur is an individual who develops and produces the businesses through creative and innovative activities, by introducing new products or services, by improving the existing methods of production or service. Thus, the competencies of entrepreneurs will make a business more successful and may lead towards its sustainable competitive advantage as well. Financial literacy is very important knowledge to entrepreneur whereby is not only factor for failure of small businesses and it consequences, as expressed by (Isabel \& Fernandes, 2015). Entrepreneurial financial literacy will lead to business growth whereby decisions as leader to advises of accountants or financial advisors need accurate understanding of financial information (Brown et al., 2006). The study therefore combined the concept of entrepreneur and financial literacy to create the independent variable. According to Beck, et al (2006), dynamic incentives was selected as a variable because it has been identified as a key determinant of microfinance performance. Dynamic incentives can take a number of forms, including adjustment of interest rates, adjustment of loan sizes, contexts, including moral hazard and adverse selection (Ahlin \& Waters, 2013). Finally, majority of management study used business performane as criterion to evaluate succesfull organizations (Richard et al, 2008). Microfinance performance was identified as the dependent variable as it is an important indicator for the successful microfinance. The configuration of the relationships among these variables was informed by theoretical arguments from the resource-based theory and contingency theory of management.

The study hypothesized that microfinance performance is contingent on the interactions between financial literacy, financial acess and dynamic incentives. The illustrative presentation of the hypothesized relationships among the variables presented in Figure 1. 


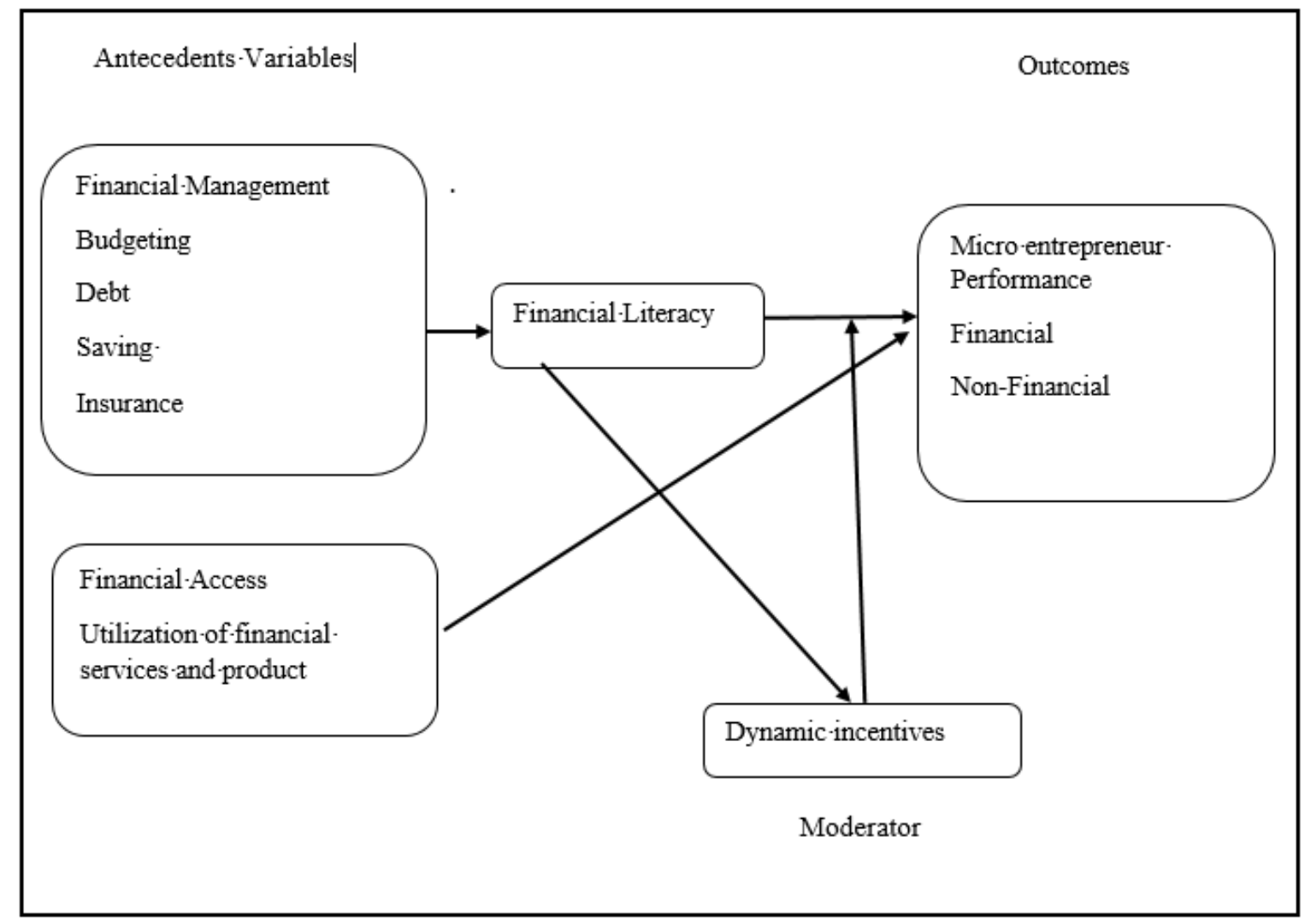

Figure 1: Proposed Conceptual Model

The conceptual framework in Figure 1 shows that all the variables are conceptualized as multidimensional constructs. A multidimensional construct is a construct involving more than one dimension. These dimensions are usually moderately correlated grouped under the same multidimensional construct because each dimension represents some portion of the overall latent construct. The complex view of multidimensional constructs that need to be discussed in order to highlight its uniqueness as compared with the factor view. They are (a) the structural relationship between indicators and the multidimensional construct, (b) the definition of error variances, and (c) the fundamental indicators of the construct vs. causes of the construct (Law \& Wong, 1999). In this study, entrepreneur financial literacy is conceptualized as a multidimensional construct comprising of five dimensions namely first, financial management, budgeting, debt saving and insurance. Secondly financial access include utilization of loans, saving, insurance, formal vs informal sources. Thirdly moderating variables which namely dynamic and lastly, financial indicators used for the study are profitability ratio, which include retgurn on assets, return on equity and operating expenses ratio. The study has one non-financial indicator namely entrepreneurial contentment. 


\section{Conclusion}

This paper proposed a conceptual framework regarding the importance of resource based view theory and entrepreneurial competencies theory towards the micro entrepreneur performance by integrating the concept of internal and external integration between the relationships of the independent and dependent variables. As the existing literature, reveals the importance of internal and external integration towards micro entrepreneur performance, this paper argues that through external integration, this relationship can be improve. This conceptual paper, suggests that an empirical study should be conduct for future research by integrating this conceptual framework with several mediators or moderators that could affect the relationships.

\section{Corresponding Author}

Habsah Mohamad Sabli*

Faculty of Economics and Business,

Universiti Malaysia Sarawak

Email: achenfardillah81@gmail.com

\section{References}

Abiodun, E. And E. H. (2016). Financial literacy and SME firm performance. International Journal of Research Studies in Management, 5(1), 31-43.

BNM. (2015). Economic and Financial Developments in Malaysia Economic and Financial Developments in Malaysia in the Second Quarter OF 2015.

Banks, C. (2010). Financial Stability And Payment Systems Report 2009 Development Of The Financial Sector, (2007), 2005-2006.

Beck, T., \& Demirguc-Kunt, A. (2006). Small and Medium-Size Enterprises: Access to Finance as a Growth Constraint. Journal of Banking and Finance, 30(11), 2931-2943. doi.Org/10.1016/J.Jbankfin.2006.05.009

Brown, R. B., Saunders, M. N. K., and Beresford, R. (2006). You owe it to yourself: The financially literate manager. Accounting Forum, 30(2), 179-191.doi: 10.1016/j.accfor.2006.03.001

De Mel, S., McKenzie, D. \& Woodruff, C. (2008). "Who are the entrepreneurs: Financial Literacy for Young Entrepreneurs? World Bank Working Paper, 5642.

Dimitratos, P., Lioukas, S., \& Carter, S. (2004). The relationship between entrepreneurship and international performance: the importance of domestic environment. Journal of International Business Review, 13(10), 19-41.

Fatoki, O. (2014). The Financial Literacy of Micro Entrepreneurs in South Africa. J Soc Sci, 40(2), 151-158. Retrieved From http://www.krepublishers.com/02-Journals/JSS/JSS-40-0-000-14-

Isabel, T., \& Fernandes, M. (2015). "Financial literacy levels of small businesses owners and it correlation with firms' operating performance" By Master in Finance Dissertation.

Jacob, K., Hudson, S., and Bush, M. (2000). Tools for Survival: An Analysis of Financial Literacy Programs for Lower-Income Families. Woodstock Institute, Chicago.

Kebede, M., Kaur, N. Jit D., \& Kuar, J. (2015). Financial Literacy and Management of Personal Finance : A Review of Recent Literatures. Research Journal of Finance and Accounting, 6(13), 92-107.

Kumar K, N. (2012). Dynamic incentives in microfinance group lending: an empirical analysis of 


\section{DEVELOPMENT}

Vol. 7, No. 3, July 2018, E-ISSN: 2226-6348 @ 2018 HRMARS

progressive lending mechanism. SAGE Open, 2(2), 1-9. Doi.Org/10.1177/21582

Law, K. S., \& Wong, C.-S. (1999). Multidimensional Constructs In Structural Equation Analysis : An Illustration Using The Job Perception And Job Satisfaction Constructs. Journal of Management, 25(2), 143-160.

Lusardi, A. (2015). Financial Literacy Skills for the 21st Century: Evidence from PISA. Journal of Consumer Affairs, 49(3), 639-659.

Lusimbo, E. N., \& Muturi, W. (2016). Financial literacy and the growth of small enterprises in kenya : a case of Kakamega central sub- county, Kenya. International Journal of Economics, Commerce and Management, IV (6), 828-845.

Man, T. W.Y., Lau. T. \& Snape, E. (2008).Entrepreneurial competencies and the performance of small and medium enterprises: An investigation through a Framework of Competitiveness: Journal of Small Business and Entrepreneurship 21, (20), 21-29.

Mandell, L. (2004), Financial Literacy: Are We Improving? JumpStart Coalition for Personal Financial Literacy, Washington, DC

Mason, C. L. J. \& Wilson, R. M. S. (2000). Conceptualizing financial literacy (Business School Research Series. Paper 2000: 7). UK: Loughborough University.

Muhammad, M. A. (2009). The combine effect of market orientation and owner/manager's innovation and business performance of small and medium sized manufacturing firms in Pakistan. Sintok, Kedah, Malaysia: PhD Thesis, UUM.

Naman, J. L. and F. D. Tuggle (May 1990). 'Toward an expert system to help entrepreneurs diagnose problems', Paper presented at TIMS/ORSA, Las Vegas.

Nawai, N., \& Shariff, M. N. M. (2012). Factors Affecting Repayment Performance in Microfinance Programs in Malaysia. Procedia - Social and Behavioral Sciences, 62, 806-811. doi.org/10.1016/j.sbspro.2012.09.136

Nunoo J \& Andoh F. (2012). Sustaining small and medium enterprises through financial service utilization: does financial literacy matter? (Unpublished Paper) presented at the Agricultural \& Applied Economics Association's 2012 AAEA.

Olsen, C., Marie, D., \& George, M. S. (2004). The Robert Wood Johnson Foundation and Administered By the College Board. Cross-Sectional Study Design and Data Analysis. Young Epidemiology Scholar Program (YES), 50.

Oseifuah, E. K. (2010). Financial literacy and youth entrepreneurship in South Africa. African Journal of Economic and Management Studies, 1(2), 164-182.

Polit, D. F., \& Beck, C. T. (2010). Generalization in Quantitative and Qualitative Research: Myths and Strategies. International Journal of Nursing Studies, 47(11), 1451-1458.

Richard, P. J., Devinney, T. M., Yip, G.S \& Johnson, G. (2009). Measuring organizational performance: towards methodological best practice. Journal of Management. 18(2), 96107.

Sabana, B. M. (2014). Entrepreneur financial literacy, financial access, transaction costs and performance of micro enterprises in Nairobi City County, Kenya. (Unpublished doctoral dissertation) University of Nairobi, Kenya

Shamsudeen, K., Keat, O. Y., \& Hassan, H. (2015). Access to microfinance as potential mediator on the relationship between microfinance awareness and entrepreneurial self-efficacy on SME Performance in Nigeria: An empirical study. Conference on Business Management Research II (CBMR II 2015), (December), 52-65. 
INTERNATIONAL JOURNAL OF ACADEMIC RESEARCH IN PROGRESSIVE EDUCATION AND DEVELOPMENT

Vol. 7, No. 3, July 2018, E-ISSN: 2226-6348 @ 2018 HRMARS

Worthington, A. C. 2004. The Distribution of Financial Literacy in Australia. Discussion Papers in Economics, Finance, and International Competitiveness. Queensland University of Technology, November. 